Litteratur

1. Solbakk JH, Pedersen R, Alnæs AH. Rituell omskjæring er ikke helsehjelp. Tidsskr Nor Legeforen 2012; 132: 134-5.

2. Giuliano AR, van der Loeff MF, Nyitray AG. Circumcised HIV-infected men and HPV transmission. Lancet Infect Dis 2011; 11: 581-2.

3. TobianAA, Serwadda D, Quinn TC et al. Male circumcision for the prevention of HSV-2 and HPV infections and syphilis. N Engl J Med 2009: 360: 1298-309

4. Status of CDC Male Circumcision Recommendations. Atlanta, GA: Centers for Disease Contro and Prevention, 2009 . www cd c.gov/hiv/topics/ research/male-circumcision.htm (13.2.2012).

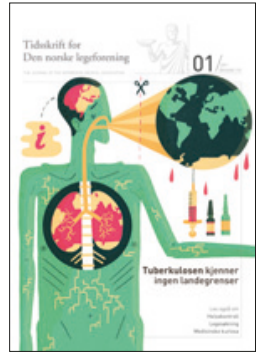

\section{Svangerskapets varighet}

I en leder i Tidsskriftet nr. 1/2012 påpeker Torvid Kiserud at svangerskapets varighet er underlagt variasjon på linje med all annen biologisk variasjon. Svangerskapets lengde vil måtte bli et evig tema så lenge man tar utgangspunktet i siste menstruasjons første dag.

Ultralydundersøkelser, som er kalibrert ut fra dette, vil måtte avsløre avvik. Eggløsningstidspunktet eller enda bedre, konsepsjonstidspunktet ville gi et bedre begrep om svangerskapets lengde. Et forhold er i hvert fall sikkert: Man er ikke gravid når man har menstruasjon; ovulasjonen finner sted to uker før menstruasjonen inntreffer.

Gestasjonsuker/svangerskapsuker har vært brukt i enkelte artikler, men før det finnes en gestasjonssekk/svangerskapssekk er det vanskelig å snakke om antall uker. I enkelte kulturer og religioner tar man utgangspunkt $\mathrm{i}$ konsepsjonstidspunktet og mener at barnet/fosteret blir besjelet i konsepsjonsuke 16, noe som tilsvarer uke 18 i den gjeldende benevnelse av svangerskapets lengde. Med den avanserte ultralydteknologien som stadig er i utvikling, må det være mulig å kalibrere seg frem til konsepsjonstidspunktet og slik få en bedre forståelse av hvor langt et svangerskap er og hvor lenge det har vart.

\section{Martin Solberg \\ Molde}

Martin Solberg (f. 1938) er pensjonert avdelingsoverlege i fødselshjelp og kvinnesykdommer, med fem år som sjeflege ved Molde sykehus.

Ingen oppgitte interessekonflikter.
Litteratur

1. Kiserud T. Hvor lenge varer et svangerskap? Tidsskr Nor Legeforen 2012; 132: 8-9.

\section{Helsebibliotekets bøker}

Vi takker for at Pernille Nylehn har tatt seg bryet med å anmelde allmennlegesiden på Helsebiblioteket.no i Tidsskriftet nr. 2/2012 (1). Konstruktive innspill stimulerer til forandring, og enkelte av forslagene er allerede tatt til følge. Listen med skåringsverktøy er revidert, og vi har en løpende diskusjon i redaksjonen om vi bør lenke opp til Pasienthåndboka.no. Pasienthåndboka.no er reklamefinansiert, og dessverre vil pasienten få en utskrift med reklame på dersom legen tar utskrift. Dette har vi til nå ansett som uheldig, og har derfor valgt å unngå lenke til Pasienthåndboka.no.

Målet med emneinngangen allmennmedisin er å skape et rom i biblioteket hvor allmennleger føler seg hjemme. Blant bibliotekets mange lenker har vi gjort et strengt utvalg for å forenkle og veilede førstegangsbrukeren. Som Pernille Nylehn nevner, har vi særlig ønsket å fremheve de frikjøpte oppslagsverkene Best Practice og UpToDate, McMasters pyramidesøk og nyhetssamlinger. Dersom man vil holde seg oppdatert på studier som forandrer praksis, kan vi sterkt anbefale UpToDates Practice Changing Updates. Ønsker man nyheter samlet fra en rekke gode kilder, vil vi fremheve samlingen «Effektiv medisinsk oppdatering».

Norsk elektronisk legehåndbok - NEL savnes i biblioteket. Etter at Helsebiblioteket betalte for tilgang til NEL i tre år, ble denne ordningen stoppet blant annet fordi prisen ble altfor høy.

Helsebiblioteket lenker ikke til NEL, ettersom vi ikke henviser til betalingstjenester. Mange allmennleger abonnerer på NEL hvor man finner svar på mange kliniske problemstillinger. Andre leger foretrekker store internasjonale oppslagsverk. Dersom man ikke finner svar i NEL, vil Helsebibliotekets oppslagsverk uansett være et godt supplement.

\section{Alexander Wahl}

Redaksjonen allmennmedisin

Helsebiblioteket.no

Alexander Wahl (f. 1963) er spesialist i allmennmedisin og redaktør for primærhelsetjenesten ved Helsebiblioteket.no, Nasjonalt kunnskapssenter for helsetjenesten.

Ingen oppgitte interessekonflikter.

\section{Litteratur}

1. Nylehn P. Biblioteket mangler en bok. Tidsskr Nor Legeforen 2012; 132: 190.

\section{Medieoppmerksomhet}

Stine Bjerkestrand setter i Tidsskriftet nr. 2/2012 søkelys på hvorfor noen studier får stor oppmerksomhet, andre ikke (1). Internett-baserte responser fra pasienter viser sterke reaksjoner på innlegget. Grunnen er vel enkel: Forskningsartiklene Bjerkestrand har valgt for å belyse poenget, synes uegnet fordi de er så forskjellige. Det ene eksemplet er Fluge \& Mellas intervensjonsstudie om behandling av kronisk utmattelsessyndrom med rituximab og det andre er Larun \& Malteruds metaanalyse om treningsbehandling. Intervensjonsstudien handler om et helt nytt funn der bruk av immunmodulator påvirker B-celler, noe som kan gi bedring eller muligens tilfriskning hos enkelte. Metaanalysen handler ikke om noe nytt, men er en oppsummering av gammel viten, særlig for pasienter som følger forskingen tett. Flere primærstudier preges av for vide inklusjonskriterier, til dels stort frafall og manglende diskusjon av frafallsårsaker. Dessuten drøftes ikke, eller i liten grad, ulike negative effekter av gradert (progressiv) opptrening. I metaanalysens diskusjonsdel er det ikke nevnt studier som dokumenterer fysiologiske forstyrrelser som kan forklare pasientenes subjektivt opplevde forverring av symptomer (2-5). Analysen gir dermed ikke en helhetlig fremstilling av nåværende kunnskapsbase om trening og fysiologiske forstyrrelser.

Fluge \& Mellas arbeid skaper håp og optimisme hos pasientene og dermed mye sterkere medierespons. Metaanalysen virker motsatt fordi pasienter opplever å bli dårligere av opptreningsregimer som Larun \& Malterud er kjente talspersoner for. Pasienter over hele verden har gjentatte ganger sagt fra uten å bli tatt på alvor. Snakker de usant? Et stadig økende antall studier av treningseffekter avdekker fysiologiske funksjonsforstyrrelser som blant annet endringer i genekspresjon (2), nedsatt evne til håndtering av $\mathrm{pH}$-forstyrrelser i muskulatur $(3,4)$ samt vesentlig redusert treningstoleranse og nedsatt cerebral oksygenering (5). Det er økende interesse blant forskere $i$ andre land for å identifisere de unormale fysiologiske mekanismene som fremkaller anstrengelsesutløst økning av utmattelse og forverring av pasientenes øvrige symptomer. Dette lover godt for den hardt rammede og dårlig forståtte pasientgruppen.

\section{Eva Stormorken}

Våler i Østfold

Eva Stormorken (f. 1953) er sykepleier med hovedfag i sykepleievitenskap og med videreutdanning i praktisk pedagogikk, anestesi, helseog sosial administrasjon. Hun er stipendiat ved Avdeling for sykepleievitenskap, Institutt for helse og samfunn, Universitetet i Oslo og medlem av Helsedirektoratets fagråd for CFS/ME. 